\title{
A case study from the southern Cape linefishery 2: \\ Considering one's options when the fish leave
}

AUTHORS:

Louise C. Gammage' (iD

Astrid Jarre ${ }^{1}$

Charles Mather ${ }^{2,3}$ iD

\section{AFFILIATIONS:}

'Marine Research (Ma-Re)

Institute, Department of

Biological Sciences, University

of Cape Town, Cape Town,

South Africa

2Department of Geography,

Memorial University,

St John's, Canada

3Department of Geography, Environmental Management and Energy Studies, University of Johannesburg, Johannesburg, South Africa

\section{CORRESPONDENCE TO:}

Louise Gammage

\section{EMAIL:}

louisegammage@gmail.com

\section{DATES:}

Received: 25 Aug. 2016

Revised: 27 Dec. 2016

Accepted: 24 Jan. 2017

\section{KEYWORDS:}

resilience; adaptation; coping; small-scale fishery; southern Benguela

\section{HOW TO CITE:}

Gammage LC, Jarre A, Mather C. A case study from the southern Cape linefishery 2 . Considering one's options when the fish leave. S Afr J Sci. 2017;113(5/6), Art. \#2016-0254, 10 pages. http://dx.doi.org/10.17159/ sajs.2017/20160254

\section{ARTICLE INCLUDES:}

$\checkmark$ Supplementary material

$\times$ Data set

\section{FUNDING:}

DST (SARChl Marine Ecology and Fisheries) through the National Research Foundation (South Africa)
Fishers in the small-scale, commercial linefishery in the southern Cape, South Africa, are exposed to variability and change in the marine social-ecological system of which they are a part. Faced with multi-scalar changes within this complex system, fishers employ a wide range of strategies in reaction to change. As part of a broader study of stressors that bring about change in these systems, this contribution examines the fishers' responses to these changes and is based on a participant-led, semistructured interview process of skippers/boat owners, crew, processors and spouses/partners, in six communities in the southern Cape region, and has been supplemented with appropriate secondary data. The results are discussed using a resilience framework. The data were initially considered thematically by stressor, but results identified that a place-based analysis was equally important. Three major groupings were identified: (1) fishers who adapt and show clear business-orientation, (2) fishers who cope, and (3) fishers who react and are thus caught in a poverty trap. In addition to place-specific history, local feedback loops and indirect effects need to be better accounted for to understand these responses to change at various scales. The results of this study are expected to contribute to the basis of scenario planning in the region.

\section{Significance:}

- Analysis of responses to change strategies provides insight into resilience displayed as well as costs and benefits of strategies.

- The description of strategies provides valuable insights into the decision-making processes in linefishery in the southern Cape.

- Cognitive and reflexive decision-making processes are shaped by individuals' and communities' experiences of past and present.

- Practical implications of actions are not always the overriding concern in decision-making, which underscores the importance and influence of culture.

- These results provide important insights into a system that is not well described, and highlight knowledge gaps that require further context-specific research.

\section{Introduction}

The failure to recognise integrated social-ecological systems in the marine environment has resulted in the depletion of ocean resources, which negatively impacts resource-dependent communities. ${ }^{1-4}$ Coastal communities that rely on fisheries are subjected to an array of political, regulatory, socio-economic and biophysical stressors ${ }^{5}$. and remain exposed to multiple stressors ${ }^{6-9}$ at various temporal and geographical scales. Response strategies to these changes, broadly classified as either reacting, coping or adapting (see supplementary material for a definition of concepts used in this paper), are also influenced by actions at multiple scales. ${ }^{10-12}$ Fishing as a livelihood is complex and dynamic, and concerns not only individuals but also households or groups attempting to make a living to meet various nutritional and economic needs..$^{13,14}$

The livelihood perspective can be used to analyse poverty, vulnerability and marginalisation at the geographical scale of experience..$^{15} \mathrm{~A}$ contemporary view of the livelihood perspective suggests that livelihoods are multidimensional and cover economic, political, cultural, social and ecological aspects of the system. Modern livelihoods are based on a range of assets, income opportunities, as well as product and labour markets located in different places and scales that also interact with other places. ${ }^{16}$ Analyses of livelihoods can free us from characterising people in singular roles (such as fishers, farmers or housewives) and instead enable us to recognise that, in order to survive in today's challenging conditions, people and households can hold diverse and various sources of support. ${ }^{17}$ Very few livelihood studies have addressed the issue of how peoples' livelihoods can cope and recover from stressors and perturbations; such studies require coupled resilience analyses which also are absent. ${ }^{18}$

The resilience perspective presents a lens through which to not only explore stresses and shocks, but also understand livelihood dynamics. Resilience in this context refers to the capacity of social units to deal with changes in the system whilst continuing to develop with a future-oriented approach and is used to characterise the system's ability to deal with change on various scales. ${ }^{19,20}$ Change and renewal may furthermore serve to nurture novelty and innovation in those social-ecological systems that are deemed to be resilient. ${ }^{13,20}$ Resilience thinking demands that 'how' and 'whether' adaptive responses are able to maintain long-term functioning of social-ecological systems, while also examining predictability. ${ }^{12,18}$ The resilience displayed by a system can be both a positive and negative attribute - whilst resilience in the system will ensure continued existence of the social units as they absorb multiple perturbations, systems that are too resilient may continue to cope and mitigate and resist adapting over the long term, even though long-term adaptation would result in a more desirable state of the system. ${ }^{11}$ It is important to discern amongst social adaptations that serve to weaken long-term social-ecological resilience (amplifying responses that result in, for example, acceleration of resource depletion) and adaptations that result in increasing 
social-ecological resilience in the longer term (dampening responses that result in, for example, a decrease in resource depletion). ${ }^{21}$ The recognition of whether and how social, economic or contextual circumstances may enable different responses is expected to provide insights into discerning which strategies can be adopted in line with conservation and/or development objectives. ${ }^{22}$ The concept of resilience can be used as an analytical approach to further the understanding of livelihoods with specific consideration given to the dynamics of how people make a living, as well as the various characteristics of complex adaptive systems with reference given to scale and uncertainty.

The Benguela Current Large Marine Ecosystem, an eastern boundary current system, sustains important fisheries for Angola, Namibia and South Africa. ${ }^{23}$ This highly variable ecosystem consists of four shelf subsystems which include the Agulhas Bank subsystem off the southern Cape coast. ${ }^{24,25}$ This study places the focus on the small-scale commercial linefishery operating on the inshore Agulhas Bank. This boat-based, multi-user and multi-area fishery exploits 50 commercially important fish species across South Africa. ${ }^{26,27} \mathrm{~A}$ variety of anthropogenic stressors including resource scarcity, poor socio-economic conditions and policy and regulatory challenges affect the inshore social-ecological system of the area. These stressors make small-scale commercial fishers and their communities increasingly vulnerable to local and global changes.$^{28}$ Fishers will in the future need to cope with and adapt to multiscalar social and ecological changes (discussed in a paired paper in this issue, Gammage et al. ${ }^{29}$ ) and communities will be required to enhance change response strategies to achieve resilience.

The fishery in this area had not had a productive or lucrative fishing season for 4-5 years prior to the study as fishers had been unable to harvest the primary target species in quantities that provide financial sustainability. Participants regard silver kob (Argyrosomus inodorus), commonly referred to as kob, as their most economically viable and sustainable target species. Although other species such as silvers/ carpenters (Argyrozona argyrozona), red fish (such as red roman, Chrysoblephus laticeps) and sharks are targeted in the absence of kob, these species are not profitable nor conducive to long-term sustainability of livelihoods. Harvesting of alternative species is a way to keep things 'ticking over', as the high-value, slow-growing red fish are scarce and fishers must travel approximately $30 \mathrm{~km}$ offshore to catch the relatively low-value silvers. Resource scarcity has led to a decrease in the number of active boats. ${ }^{30}$ The analyses presented focus on the responses to the following questions:

- What strategies do fishers' implement in response to the changes caused by the stressors that have been identified?

- Are there any groupings of strategies, relevant for future management, that can facilitate increased resilience in this area?

\section{Research area and methodology}

Participant-led research was carried out in the small-scale commercial linefishery of the southern Cape. The research area encompasses the communities of Mossel Bay, Gouritsmond, Still Bay, Melkhoutfontein, Vermaaklikheid and Witsand (see Figure 1 of Gammage et al. ${ }^{29}$ ). The interviews took place between July 2013 and February 2014. A total of 50 individuals comprising skippers, boat owners, crew, members from associated industry and spouses/partners participated. The participants dictated the scope and structure of the semi-structured interviews, which aimed at understanding stressors on their livelihoods and responses to these stressors. More details on the research area and methodology are provided in the paired paper. ${ }^{29}$

\section{Results and discussion}

Box 1 provides a few selected quotes (organised per theme) from the study respondents to contextualise fishers' experiences. Important context for the results is that fishing rights conditions prohibit fishers from holding other formal alternative sources of income; the range of economic activities and employment opportunities are limited; and there is a high dependence on the national social grant system by members from poorer communities such as Vermaaklikheid and Melkhoutfontein. ${ }^{30}$

Current change response strategies for the overall research area are provided in Tables 1 and 2. Data were initially considered thematically, as shown in these tables, but subsequent analyses identified a spatial variation in responses between different towns.

Box 1: Pertinent statements, arranged according to theme, from participants in the small-scale commercial linefishery in the southern Cape regarding their response to recent change

\section{Increase and/or decrease in effort}

I'm on the go; I have a system that works for me. There are times I will have four days in a month that I go to sea instead of 15 times. It does not help to go to sea every day. - Skipper, Witsand (2014)*

\section{Other employment (formal and informal)}

We as fishermen may not have another income, but some fishermen help with construction projects because they know if there is fish to be caught, they can go to sea. - Rights holder, Still Bay (2013)*

Sam himself did the spray jobs this year so we employed one or two guys this year to help us. We try when (or what is supposed to happen), when the fishing is good, we are supposed to pack away money. Literally, Sam ties his own boat up, um say from July to especially end of August. And that time he will do building and refurbishments. And then he will get his crew in to help with the fibre glassing and spraying and that is how it is actually supposed to work. - Spouse, Still Bay (2013)

Spousal income

Most of the women have a sort of a job. Most of them. - Skipper, Vermaaklikheid (2014)

Migration (temporary)

The thing is that as the fish become scarce, then the fisherman takes his basket and he goes to Mossel Bay or Knysna, so that guy is not tied to the boat, you understand, if it gets bad then he walks. - Skipper, Witsand $(2014)^{\star}$

\section{Leave fishery}

Financing is the main reason [for choosing to exit the fishery] in the entire industry. It just costs too much money. If only the state could subsidise the fuel, even if only by $50 \mathrm{c}$, it would make a man's life much easier. And this is really the biggest thing. Financing. No one has money today to go to sea. - Skipper, Still Bay (2013)*

\section{Change of fishing strategy}

We have had to change our way of fishing, the ski boat's running costs are ridiculously high (as we know), and the brunt of us are onto deck boats, which are tied up in the harbour and currently we are fishing 81 nautical miles out on the Alphard Banks because that is the only place that we can edge out a living. - Skipper, Mossel Bay (2014)

\section{Downscaling}

Suppose I catch $50 \mathrm{~kg}$ with a small boat and I caught $50 \mathrm{~kg}$ on the big boat then it means that I do not make money when I use the big boat. - Skipper, Melkhoutfontein (2014)*

${ }^{*}$ Responses translated to English from Afrikaans 
This resulted in three main groupings of responses: communities of fishers - from Mossel Bay, Witsand and Gouritsmond - who appear to be adapting in the long term ('business-oriented fishers'); those, from Still Bay and Melkhoutfontein, who are coping ('coping fishers'); and those, from Melkhoutfontein, who are reacting ('reacting fishers'). The first group indicated that 'riding out the storm' and/or changing fishing strategy were preferred strategies. The second group indicated that their most widely implemented livelihood strategy was 'riding out the storm', with many also seeking alternative informal employment whilst decreasing catch effort. Fishers from Vermaaklikheid mostly chose to 'ride out the storm' whilst seeking alternative informal employment and relying on spousal income and/or social grants.

\section{Mossel Bay, Witsand and Gouritsmond: The business- oriented fishers}

This group of fishers was characterised by a change in fishing strategy classified as diversification (craft, target areas, leaving fishery and engaging in alternative industry); intensification of fishing effort; and 'riding out the storm' (Table 3). This response was largely made possible by effective operation of the fishery as a small business enterprise.

Table 1: Response strategies for which a positive response was recorded by more than $40 \%$ of the participants

\begin{tabular}{c|l|l}
\hline \hline \multicolumn{1}{c|}{ Strategy (theme) } & Percentage of participants & \multicolumn{1}{c}{ Characteristics of strategy (from fisher data) } \\
\hline 'Ride out the storm' & \multicolumn{1}{|c|}{$82 \%$} & $\begin{array}{l}\text { Try to 'get by' on a day-to-day basis } \\
\text { Proceed to sea when they have money for input costs (bait and diesel) }\end{array}$ \\
\hline Other (informal) employment & \multirow{2}{*}{$\begin{array}{l}\text { Used in conjunction with other strategies like 'riding out the storm' } \\
\text { Range of informal activities engaged in include wood gathering and gardening }\end{array}$} \\
\hline Spousal income & $\begin{array}{l}\text { Additional employment opportunities arise in peak holiday periods } \\
\text { Some participants engage in activities that draw on previous experience, e.g. boat maintenance, } \\
\text { panel beating, bee-keeping. The crew is employed should assistance be required. }\end{array}$ \\
\hline \multirow{2}{*}{$48 \%$} & $\begin{array}{l}\text { An important but undervalued strategy } \\
\text { Spouse/partner often provides stable income through formal and informal employment } \\
\text { Government social grants also provide an income source (e.g. child/disability grants) }\end{array}$ \\
\hline
\end{tabular}

Table 2: $\quad$ Response strategies for which a positive response was recorded by less than $25 \%$ of participants

\begin{tabular}{|c|c|c|}
\hline Strategy (theme) & Percentage of participants & Characteristics of strategy (from fisher data) \\
\hline Decrease effort & $24 \%$ & $\begin{array}{l}\text { Only proceed to sea when profitable catch guaranteed (accomplished by relying on feedback from other } \\
\text { fishers as well as own knowledge of local weather and sea conditions) } \\
\text { Allows fishers to stay engaged in fishery as fishing is seen as a way of life, not just a job }\end{array}$ \\
\hline Change fishing strategy & $20 \%$ & $\begin{array}{l}\text { Implement a long-term or permanent change to the way they fish } \\
\text { Change their fishing craft (ski boats to deck boats, outboard motors to inboard diesel engine), which } \\
\text { reduces input costs such as fuel, and allows for an increase in range and decrease in maintenance costs. } \\
\text { Mainly Mossel Bay fishers engage in this strategy. }\end{array}$ \\
\hline Other employment (formal) & $14 \%$ & $\begin{array}{l}\text { Fishers indicate that local employers (such as builders) do not want to hire fishers as they are not reliable } \\
\text { (will abandon job as soon as fishing is viable again) } \\
\text { Fishers are not permitted by conditions of rights to hold alternative employment }\end{array}$ \\
\hline Leave fishery & $16 \%$ & $\begin{array}{l}3 \text { participants had already left fishery } \\
5 \text { indicated they were considering it } \\
\text { Indications are the fishers leave when it becomes too difficult to 'make ends meet' }\end{array}$ \\
\hline Downscale & $11 \%$ & $\begin{array}{l}\text { Larger boats with outboard motors may go faster and further, but with elevated associated running costs } \\
\text { which is a burden to the boat owner/skipper } \\
\text { Participants indicated that they opted to buy small boats and motors to counteract the larger costs of } \\
\text { larger boats }\end{array}$ \\
\hline Migrate (temporarily) & $12 \%$ & $\begin{array}{l}\text { Travel to Cape Town to catch snoek (Thyrsites atun) in winter (kob off-season) } \\
\text { Mostly crew who engage in this strategy as they can move between management areas } \\
\text { Most participants unwilling to engage in this strategy as it is not necessarily financially viable (additional } \\
\text { costs of 'second household') } \\
\text { Participants also indicate unwillingness to migrate temporarily because of a sense of wanting to be 'home' }\end{array}$ \\
\hline Increase effort & $12 \%$ & Accomplished by targeting slower-growing reef (red) fish in absence of kob \\
\hline
\end{tabular}


Table 3: $\quad$ Change responses implemented by the fishers from Mossel Bay, Gouritsmond and Witsand: business-oriented fishers

\begin{tabular}{|c|c|c|c|c|c|c|c|c|c|c|c|c|c|c|}
\hline & Role & & Tow & & & & & & & & & & & \\
\hline & 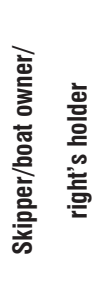 & 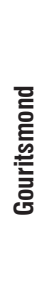 & 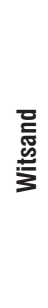 & 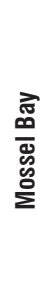 & 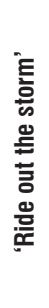 & 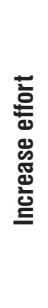 & 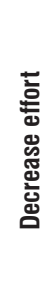 & 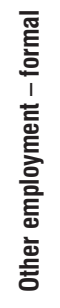 & 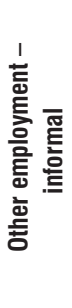 & 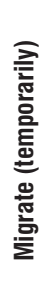 & 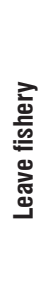 & 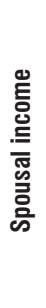 & 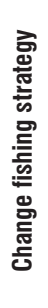 & 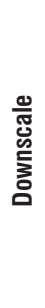 \\
\hline Participant 8 & - & & & • & - & - & & & & - & & - & - & \\
\hline Participant 41 & • & & & $\bullet$ & - & & & & & & & & • & \\
\hline Participant 42 & • & & & - & - & & & & & & & & • & \\
\hline Participant 43 & • & & & $\bullet$ & - & & & & & & & & • & \\
\hline Participant 44 & $\bullet$ & & & $\bullet$ & - & & & & & & & & • & \\
\hline Participant 31 & • & - & & & & & & - & & & - & & & \\
\hline Participant 50 & • & & - & & - & & - & & - & & & • & - & \\
\hline Total & 7 & 1 & 1 & 5 & 6 & 1 & 1 & 1 & 1 & 1 & 1 & 2 & 6 & 0 \\
\hline
\end{tabular}

Diversification as a fishing strategy took the form of a change in fishing craft from ski boats to deck boats, as well as a change in target species. Ski boats place constraints on the volume of landed catches, provide no space for ice or refrigeration, and pose operational constraints in terms of sea state and duration of fishing trips. In contrast, the range of deck boats is significantly further and they can operate in rougher weather while extending the duration of trips. However, deck boats are slow, require large capital investment and need a longer window of favourable fishing conditions. Fishers who transitioned to deck boats attributed the decision to high running costs associated with outboard engines normally fitted on ski boats. Deck boats have diesel engines and diesel is subsidised for certain sectors with users able to reclaim valueadded tax (VAT). Diesel engines, although more expensive to maintain, require less regular maintenance than outboard motors and users maintained that these engines are less 'temperamental'. In the present economic climate, benefits of using diesel engines far outweighed the risks according to these fishers. Additionally, the change to deck boats resulted in extending fishing activities to habitats such as the Alphard Bank (see Figure 1 in Gammage et al. ${ }^{29}$ ), previously unexploited by these fishers from Mossel Bay. At the time of the study, only a single linefisher from Mossel Bay still utilised a ski boat, although this boat was also fitted with an inboard diesel engine.

The use of deck boats was not only a form of diversification, but also an example of 'intensification of effort', generally linked to fishing 'harder' on the same stocks in an area. ${ }^{31}$ This intensification is depicted through the extension of fishing trips on both temporal and spatial scales, as well as fishing in poor conditions that could increase safety risks. The longterm sustainability of this strategy is questioned as intensified effort may impact the biophysical environment negatively as a result of increased fishing pressure on already fully- or over-exploited stocks. . $^{27,32}$

It is not easy to attribute definitive reasons for diversification and restructuring taking place in the Mossel Bay linefishery. Sufficient capital was required for these craft fishers to diversify. The diversification of craft was a business-oriented decision, indicative of the way that the participants approached fishing activities. Participants acknowledged that to keep fishing, their fisheries needed to be managed as a business. Why this business acumen was not evident throughout the study area remains unclear. In terms of Mossel Bay, it may be that competition stemming from the proximity of more industrialised fisheries, notably bottom trawling ${ }^{33}$, has forced the linefishery in the area to adopt more structured business practices to secure and maintain viable market share. The relatively advanced state of infrastructure development encountered in Mossel Bay is also important as Mossel Bay is the only town in the research area that has suitable berthing for deck boats. The context and scale of the town appears to have an influence on how fishers choose to manage rights.

It is relevant to view the capacity for informed decision-making and business acumen in the context of South Africa's history of racial segregation and its after-effects. This group of participants comprised white men who likely had had access to secondary school education. Most of these fishers would have had to do compulsory military service upon leaving school, exposing them to other skills and environments. Issues of race, education and gender may play a very important role in how this group can respond to change. However, the analysis of individual life histories and their impacts is not within the scope of this paper. It remains important that the role these histories play in decision-making and in the ability to implement certain strategies be acknowledged and further explored in future.

Apart from the general business acumen displayed by this group, the remaining ski-boat operator intensified his effort by targeting slowgrowing, high-value reef fish through spending every available moment at sea. He also displayed contradictory characteristics in terms of his willingness to work with others. To a certain extent, this participant was a 'lone wolf', as his work ethic and intensity of effort set him apart from most participants. He did not overtly display cooperation with other fishers to make 'finding the fish' easier and did not appear to benefit from the support of social networks. The ski-boat operator from Mossel Bay also adapted his fishing methods by utilising a technique called riemhou that 'involves the skipper keeping the boat positioned directly above the swimming shoal while it feeds on the edge of the reef'34(p.12). This method requires great skill and is becoming increasingly popular amongst younger skippers. Opponents to the method feel that continuously running engines chase the fish away. However, this strategy remained highly successful, albeit costlier, for those fishers utilising the method.

While all the Mossel Bay deck-boat fishers adapted in the longer term, they did not appear to have alternative future strategies in place. This absence came to the fore when voicing concerns over the outcome of the medium-term fishing rights allocation process of 2013 (FRAP 2013) 
that was ongoing during the research period. This highlights that even when adaptation has taken place, the constant system flux requires that fishers remain dynamic and proactive in their responses.

It is unclear how many fishers remain active in Gouritsmond. The Gouritsmond participant for this study was no longer involved in commercial fishing as he had surrendered his fishing right. Instead, this participant opted to diversify outside the fishery by operating fishing charters and other businesses such as accommodation letting through capitalising on seasonal tourism. This diversification of economic activities in order to establish a steady stream of alternative income sources ${ }^{14}$ is in direct contrast to the diversification displayed by other participants in this group. The decision to exit the fishery is an affirmation of this participant's business acumen. He was previously a successful farmer and engaged in commercial line fishing as a form of retirement. Gouritsmond, relatively close $(46 \mathrm{~km})$ to Mossel Bay, is a small holiday town with few permanent residents and considerably less competition from other commercial fishers in the immediate vicinity. The proximity to the larger urban area also allows for convenience in a quiet, rural town setting whilst offering alternative business opportunities upon which to capitalise.

The sole commercial linefisher in Witsand implemented several measures that allowed him to continue to earn an income primarily from fishing. Apart from spousal support and livelihood diversification in the form of activities like helping farmers chase baboons off farms, the Witsand fisher was set apart from all study participants in the way that he managed his fishing right allocation. This participant created a closed corporation (cc) in which his crew were named shareholders with a profit share agreement in place. The cc bore the cost of 'boat rental', maintenance and other expenses. Profits after salaries, were paid out periodically. This approach ensured that a monthly stipend was available to the crew members as part of the profit-share agreement during the off-season. This strategy allowed the fisher to manage his fishery as a responsible business. Apart from procedural and administrative problems encountered with FRAP 2013, the Witsand participant scored well and retained his right. It should be noted that the crew resided outside of the study area and thus their views were not included in this analysis.

Witsand has a strong fishing history and, unlike the other towns in the research area, fishing has always been the primary livelihood activity, whereas in Still Bay, Melkhoutfontein and Vermaaklikheid, the primary livelihood activity has been agriculture. ${ }^{33}$ The participant from Witsand is a descendant of one of the town's original fishers and took up commercial fishing in the mid-1990s after spending his early career in formal employment. The experience gained from this earlier employment, coupled with his strong fishing heritage, likely played a central role in his continued trade as a fisher. Opportunities to diversify outside the fishery while remaining in Witsand were rare because of the small size and holiday resort nature of the town, and most fishers had been forced to move away to pursue alternative livelihood opportunities.

Household- and community-level decisions regarding investments reduced dependence on external initiatives (e.g. fish buyers and their marketing networks); stronger contacts with local decision-making are important when examining why different communities respond differently to the same stressors. The fishers of Mossel Bay, in contrast to many other fishers in the region, appeared to be a relatively tight-knit group involved in local and national associations and displayed some teamwork. This was also true for the participant from Witsand - being the sole commercial fisher in the town at the time of the research, he chose to network closely with some of the Mossel Bay fishers. As these two towns are geographically quite far apart (156 km by road) the likemindedness within this group facilitated this cooperation, which can be viewed as a contributor to their success.

\section{Still Bay and Melkhoutfontein: The coping fishers}

The second group of participants comprised fishers from Melkhoutfontein and Still Bay. Still Bay is a middle- to upper-income town with predominantly white residents, both historically and currently, while
Melkhoutfontein is a middle- to low-income town with predominantly Coloured residents, both historically and currently. Still Bay provides most of the livelihood diversification opportunities for both towns. Although social and economic conditions in these two towns are very different, the fisheries are intrinsically linked as they utilise the same facilities, sell to the same suppliers and have displayed a similar developmental trajectory. ${ }^{33}$ Participants experienced impacts of stressors differently between the two towns where the capacity to respond was influenced by factors such as access to capital, knowledge base (education level) and alternative skill sets. ${ }^{35,36}$

Strategies employed by this group fell into the following categories: diversification outside the fishery, riding out the storm and decreasing effort (Table 4). Fishers were faced with infrastructure constraints when considering alternative options in terms of diversification within the fishery. Still Bay has no available berthing for deck boats and limited facilities for processing, storage and distribution of fish. The fishers from this group used strategies that relied on other skill sets, as well as spousal support and reliance on government grants for those who qualified. Decision-making was largely driven by the availability of capital and human resources.

It is possible to identify two subgroups within the coping fishers. The first subgroup is fishers who had alternative income sources (such as a pension, investment income, rental income, more formal secondary livelihood activities), as well as access to larger amounts of capital through financing, sale of businesses, (early) retirement and/or severance pay. This income provided a certain amount of financial security when fishing-derived income was insufficient. Almost half of the participants indicated that they had previously engaged in other full-time economic activities before taking up commercial fishing and thus had alternative skill sets. Skill sets included repairing boats and outboard motors, panel beating and spray painting services, renting out accommodation, subsistence farming, bee-keeping and operation of boat charters. Such activities can generate decent amounts of income in contrast to informal, less-skilled employment. Access to alternative sources of income allowed these fishers to effectively 'ride out the storm' as they did not find it necessary to implement long-term responses, even if they had the resources to do so at their disposal. For example, this subgroup of fishers opted to keep on using petrol outboard motors as opposed to diesel inboard engines despite objecting to rising petrol costs.

The second subgroup comprised participants who were primarily fishers for most of their working lives. This group did not have, nor had ever had, access to large amounts of capital and had limited access to stable alternative income sources, forcing many to take up unskilled, informal and temporary employment. Opportunities for these fishers were generally low paying and unsustainable over the long term and included activities such as gardening, painting, construction work and temporary employment within other fishing sectors. These fishers therefore tended to engage in a 'hand-to-mouth' existence. Within this subgroup there were fishers who attempted to plan and save money for unforeseen circumstances, but limited access to pre-existing financial capital or skilled opportunities constrained possibilities to diversify livelihoods. This highlights that strategies can be inhibited by financial resources and poorer fishers tend to find themselves unable to adapt to changes even if they wish to do so.

The coping fishers group displayed an immense amount of optimism when viewing the future of the industry, although the presence of alternative strategies indicated that the fishery was not able to singularly support their livelihoods at that time. This behaviour rests on fishers' supposition that fishing will always remain their primary source of income and fishers explicitly stated that they did not wish to do anything but fish. The long-term sustainability of this strategy must be called into question as many of these fishers' livelihoods were only secured when a consistent and substantial income could be derived from fishing.

As a result of the consistently poor kob catches, even fishers with contingency funds and plans had depleted their financial reserves and indicated that it was becoming increasingly difficult to fund trips to sea. They subsequently decreased their effort and carefully selected days on which to go fishing, which were dependent on the probability of a good catch. 
Table 4: Change responses implemented by the fishers from Still Bay and Melkhoutfontein: coping fishers

\begin{tabular}{|c|c|c|c|c|c|c|c|c|c|c|c|c|c|c|c|c|}
\hline & \multicolumn{4}{|c|}{ Role } & \multicolumn{2}{|c|}{ Town } & \multicolumn{10}{|c|}{ Strategy } \\
\hline & 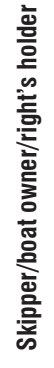 & 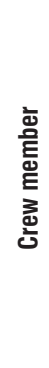 & 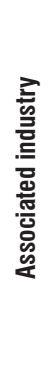 & 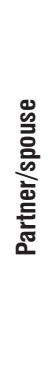 & 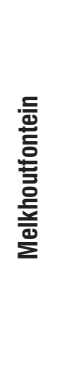 & 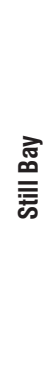 & 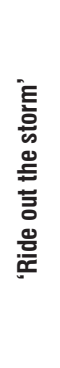 & 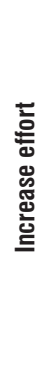 & 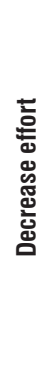 & 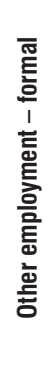 & 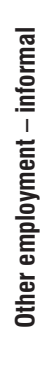 & 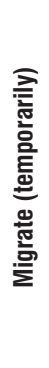 & 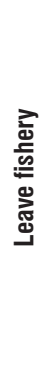 & 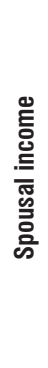 & 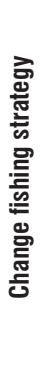 & 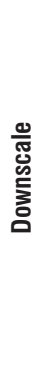 \\
\hline Participant 1 & - & & & & • & & • & & • & & - & & & • & & • \\
\hline Participant 4 & & & & • & & - & - & & - & & & & & • & & \\
\hline Participant 5 & - & & & & & - & • & & & & - & • & • & & & \\
\hline Participant 6 & • & & & & & • & • & & - & & • & & • & • & & \\
\hline Participant 7 & • & & & & - & & • & & & & & • & • & • & & • \\
\hline Participant 9 & & - & & & • & & • & & & & • & & & • & & \\
\hline Participant 12 & & & • & & & - & & & & & & & & & & \\
\hline Participant 13 & & & • & & & • & & & & & & & & & & \\
\hline Participant 14 & & & • & & & • & • & • & & & • & & & & & \\
\hline Participant 15 & & & • & & & • & • & • & & & • & & & & & \\
\hline Participant 32 & - & & & & & • & & & & & & • & & & & \\
\hline Participant 33 & • & & & & & • & • & & • & & & • & & • & & • \\
\hline Participant 34 & & - & & & & • & • & & • & • & & & & & & • \\
\hline Participant 35 & & & • & & & • & & • & • & & & & & & • & \\
\hline Participant 36 & & & & • & & • & & & & & & & & & & \\
\hline Participant 37 & & & • & & & • & • & & & & • & & & & • & • \\
\hline Participant 38 & & & • & & • & & • & & & & • & & • & • & & \\
\hline Participant 39 & & • & & & • & & • & & • & & • & & & • & & \\
\hline Participant 40 & & • & & & - & & • & & - & & • & & & • & & \\
\hline Participant 45 & & & • & & & • & & & & & & & & & & \\
\hline Participant 46 & & & • & & & • & • & & & & • & & • & • & & • \\
\hline Participant 47 & • & & & & & • & • & & • & & • & & & & & \\
\hline Participant 48 & • & & & & & • & • & & - & & • & - & & • & - & \\
\hline Participant 49 & • & & & & & • & • & & • & & • & & & & • & \\
\hline Total & 9 & 4 & 9 & 2 & 6 & 18 & 18 & 3 & 11 & 1 & 14 & 5 & 5 & 11 & 4 & 6 \\
\hline
\end{tabular}

Although fishers targeted less lucrative fish in the absence of kob, this option could result in higher fishing costs. Many fishers resorted to borrowing money from other fishers and/or intermediaries who buy the catch. ${ }^{29}$

The 'coping' group displayed less business acumen than the businessorientated fishers. As fishing-derived income declined, many of these coping fishers may not have been financially secure to comply with requirements that bear financial stipulations. Consequently, most rights holders in this group did not score well in terms of the balancing and evaluation criteria (see Gammage et al. ${ }^{29}$ ) set out by FRAP 2013.
The failure to secure a right is a cataclysmic event forcing fishers to either diversify outside the fishery or continue fishing commercially (albeit illegally) or recreationally. Notwithstanding shortcomings in previous and current rights allocation processes, much of the uncertainty and ensuing risk could be avoided if fishers were in a position (in terms of access to capital and skills) in which they could comply with the criteria. The inability to manage rights optimally had made these fishers more vulnerable to changes on multiple scales, as they were not only unable to sustain themselves and their crew in the 'off season', but risks posed by policy and regulatory requirements were also exacerbated. 


\section{Vermaaklikheid: The reacting fishers}

Situated on the banks of the Duivenhoks River, Vermaaklikheid consists predominately of holiday houses surrounded by agricultural land. All participants from this area were from the Coloured community and reside on what is known as 'the Koppie' (small hill in Afrikaans). The participants hailed from a primarily subsistence fishing community that previously fished in the Duivenhoks River and from the shore at Puntjie (located on the east bank of the Duivenhoks River mouth). At the time of the study, fishing activities were limited to acting as crew for three small-scale commercial boats that operated in the area.

Strategies employed to deal with change can be broadly characterised as: livelihood diversification, riding out the storm and restructuring (Table 5). However, opportunities for diversification and restructuring were severely constrained by social and environmental stressors, resulting in a 'hand-to-mouth' existence for this group. While some of the constraints emanated from the rural nature of the town that gave rise to infrastructure challenges, prevailing economic and social conditions (poverty and low education) played a central role.
A large amount of hopelessness was expressed by Vermaaklikheid participants when considering present and future situations. Participants felt powerless to solve their problems at both community and individual levels and expressed hope for some external intervention to resolve challenges. Responses were generally very emotive, which influences how communities can plan when subjected to multiple hardships by undermining their ability to adapt to and/or cope with stressors that seem to be less 'blameworthy' but more quantitatively important. ${ }^{12}$

Vermaaklikheid is geographically isolated and only accessible by two gravel roads that connect to Riversdale $(34.3 \mathrm{~km})$ and Still Bay $(43.1 \mathrm{~km})$. At the time of the study, there was no public transport servicing the community whilst only one community member from the Koppie owned a vehicle. Although this community member provided a transport service to Riversdale, it was nevertheless costly for participants who did not have a steady income. The need to travel to Riversdale was a practical one as there was only one informal shop in the area which charged exorbitant prices for basic food items. Women tended to take responsibility for the procurement of basic foodstuffs and other goods with a spirit of cooperation between them to surmount practical challenges.

Table 5: Change responses implemented by the fishers from Vermaaklikheid: reacting fishers

\begin{tabular}{|c|c|c|c|c|c|c|c|c|c|c|c|c|c|}
\hline & \multicolumn{3}{|c|}{ Role } & \multicolumn{10}{|c|}{ Strategy } \\
\hline & 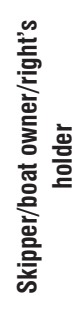 & 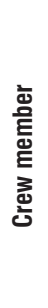 & 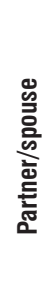 & 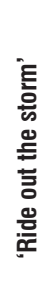 & 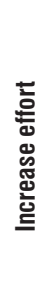 & 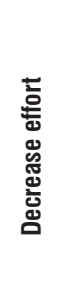 & 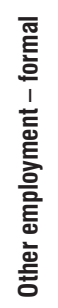 & 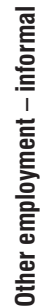 & 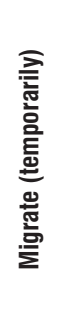 & 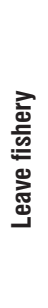 & 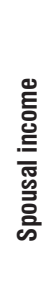 & 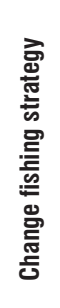 & 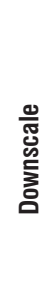 \\
\hline Participant 2 & & - & & - & - & & - & & & & • & & \\
\hline Participant 3 & & & • & & & & & & & & & & \\
\hline Participant 10 & & & - & - & - & & & • & & & & - & \\
\hline Participant 11 & - & & & & & & & & & • & & & \\
\hline Participant 16 & - & & & - & & & & • & & & & & \\
\hline Participant 17 & • & & & • & & & & • & & & • & & \\
\hline Participant 18 & & - & & • & & & & • & & & • & & \\
\hline Participant 19 & & • & & • & & & & • & & & • & & \\
\hline Participant 20 & & • & & • & & & & • & & & • & & \\
\hline Participant 21 & & • & & • & & & & • & & & • & & \\
\hline Participant 22 & & - & & • & & & & - & & & • & & \\
\hline Participant 23 & & - & & • & & & & • & & & • & & \\
\hline Participant 24 & & - & & • & & & & • & & & - & & \\
\hline Participant 25 & & • & & • & & & & • & & & • & & \\
\hline Participant 26 & & & - & • & & & & • & & & • & & \\
\hline Participant 27 & & & - & • & & & - & • & & & & & \\
\hline Participant 28 & & & - & - & & & • & • & & & & & \\
\hline Participant 29 & & & - & • & & & - & • & & & & & \\
\hline Participant 30 & & & - & - & & & - & • & & & & & \\
\hline Total & 3 & 9 & 7 & 17 & 2 & 0 & 5 & 16 & 0 & 1 & 11 & 1 & 0 \\
\hline
\end{tabular}


This cooperation was evident in the way that they shared transport costs, took turns to do shopping and generally helped each other making this one of the most important coping strategies displayed by this community. $5,9,12$

Participants observed that the transformation of the area from productive farms to holiday houses and non-crop farms had resulted in the systematic reduction of employment opportunities. As agricultural activities and associated employment decreased, fishing became an increasingly important livelihood strategy. Participants indicated that farmers previously allowed employees to plant small vegetable patches and/or gardens on their land to improve overall food security. Importantly, while government provided housing to eligible communities in Vermaaklikheid, members held no communal land on which to implement projects such as a community garden. One ex-fisher, with the assistance of the Department of Agriculture, Forestry and Fisheries and the Department of Trade and Industry, engaged in subsistence chicken farming as part of a programme in which beneficiaries were trained and given a 'starter kit' of chicks. This participant could undertake chicken farming as he owned a smallholding in the area. Importantly, he did not leave the fishery by choice, but eventually gave up after experiencing practical challenges related to the rights application process.

In this area, subsistence fishing as a livelihood strategy was curtailed by the removal of access to the Duivenhoks River. Fences were erected to demarcate farm boundaries which blocked pedestrian access to the coast, further impeding community access to traditional fishing spots. Skippers operating in the area provided an opportunity for employment as crew, although not without constraints. Fishers were forced to either launch boats in the river and proceed to sea through the river mouth or travel to Still Bay via road. Neither of these options was viable as travelling an excess of $80 \mathrm{~km}$ by road per day contributed to input costs and the poor condition of access roads posed safety risks. The option to launch in the river was only viable in favourable weather conditions; however, viable sea days were perceived by participants to be decreasing. The high unemployment rate in this community implied that available crew members exceeded requirements. Notably, not all crew were traditional fishers, but in the absence of alternative employment opportunities in Vermaaklikheid, crewing remained a popular and potentially lucrative activity.

Participants diversified outside the fishery by engaging in informal economic activities such as alien vegetation clearing and garden services. Harvested wood from these activities was sold to holidaymakers and residents which, in periods of high demand, could be a lucrative undertaking. This strategy had mixed success as landowners did not necessarily invite the woodcutters onto the land. Problems included the fire risk posed by the remaining wood and responsibility for removing leftover vegetation reverting to the landowner. Woodcutters disagreed and felt that they were doing the landowner a favour as alien vegetation would have had to be cleared. ${ }^{37}$ Gardening and caretaker opportunities were rare, as many houses were holiday houses and owners were weary of letting strangers work on their property in their absence.

Conversations with the community on the Koppie revealed deep-seated mistrust existing along racial lines. This mistrust is not surprising as the lingering legacy of South Africa's political past is more prominently felt and seen in rural areas - an experience echoed by numerous communities across South Africa. 38,39 Distrust results in a failure to engage in conflict resolution and the implementation of communityfocused change response strategies such as coping or adaptation to change. Concern was also raised around low education levels in this community. Coupled with the remoteness of the town, lack of education is a major contributing factor to poverty and can limit livelihood options. ${ }^{38}$ One resident (also a participant) recognised this problem and used her expertise to start an independent community school. This venture received no support from government and was funded by an organisation based in the USA. This example highlights that community support from local structures was limited and, apart from private citizens who offered donations or initiatives, there was little support from external institutions and structures.
In the consideration of future options, participants expressed an unwillingness to migrate, albeit temporarily or permanently, because of their connection to the place, which outweighed livelihood struggles endured. Participants noted that migration to larger urban areas did not necessarily guarantee employment or improved living conditions. Any out-migration can fracture communities, break networks and transform relationships, which can subsequently alter the mood of the community when social relations are changed. ${ }^{9}$ Instead, it is preferable that communities and households rather be encouraged to maintain diverse livelihood portfolios that include the development of subsistence activities, ${ }^{12,40}$ which in this case also appeared unattainable.

\section{Comparison between groups}

The three groups of fishers presented in this paper all displayed varying levels of resilience. This resilience can have both positive and negative consequences for individuals and communities. Whilst the presence of resilience can lead to the creation of opportunities and innovation within a system, too much resilience may have negative consequences as systems continually return to the original (and at times unsustainable) state once stressors abate..$^{19,36}$

The business-oriented group had already adapted over the long term and any resilience displayed by them was in the context of strategies implemented. While this group displayed resilience, these large and permanent diversification measures that had already been implemented may make it very difficult for these fishers to respond dynamically to further stressors and/or shocks. Although the group's overall resilience after recent diversification may not be very strong, it is important to note that the individuals in this group displayed a fair amount of resilience as they could sustain their livelihoods through their fishing activities, despite adversity.

To understand the notable difference in strategies implemented by fishers from the different groups in which social and economic conditions and levels were similar or the same, it is important to consider the life histories and social contexts of the inhabitants of the different towns. Historically, the fishers from the towns that form the 'coping group' and 'reacting group' were not exclusively fishers and instead engaged in a wide range of activities to secure livelihoods, with fishing being a secondary source of food and income..$^{33}$ This is in direct contrast to those from Mossel Bay who had a strong history of commercial and industrialised fishing ${ }^{33}$, and Witsand which was originally established as a fishing town ${ }^{41}$. This history has directly contributed to the variation of change response strategies observed in the research area.

The coping group was the most resilient of the groups, as strategies employed by this group were temporary and these fishers reverted to fishing as the main livelihood income only when conditions were conducive for fishing. Fishers from the coping group highlighted barriers to proposed future alternatives, which is in direct contrast to the optimism displayed when discussing the viability of fishing as a long-term livelihood strategy. This reticence may be indicative of general resistance to permanent long-term change (i.e. adaptation) and if the current status quo is maintained, it will become increasingly difficult to transform the current, resilient system to a state that is more appropriate and suitable. ${ }^{19,42-44}$

The resistance to change displayed by the coping group must also be viewed in the context of the systematic marginalisation of commercial linefishers that has resulted in the creation of a long-existing policy 'grey area'. The implementation of the Marine Living Resources Act and ensuing regulatory climate (see Gammage ${ }^{30}$ ) has steadily closed this policy gap. Once the Small-scale Fisheries Policy (No 274 of 2012) has been fully implemented, current rights holders will be forced to choose between staying in the commercial fishery which will require compliance with regulations where a business-oriented approach is necessary, or alternatively becoming part of a community right, thereby effectively forcing a long-term adaptive change.

In contrast to the business-oriented group, diversification options and opportunities for the fishers of both the coping and reacting groups are limited by geography, infrastructure and economics. Many of the coping 
fishers from Still Bay who have left the fishery have subsequently left the geographical area. The same is not true for Melkhoutfontein-based fishers, as they did not necessarily have the financial means to leave the area. The inability to access capital and resources needed to diversify, whether within or outside the fishery, is a large stumbling block when considering responses to change by all groups on all temporal scales. Furthermore, although better access to financial capital will enable fishers to implement more sustainable and long-term adaptive strategies, it is the social capital and knowledge held by the fishers that will allow them to recognise the need to adapt. The recognition of a problem and the ability to forecast and evaluate change is not only the first step in building resilience, but also the most important one..$^{19}$ Although the fishers of the coping group displayed a large amount of resilience, their responses indicate that decision-making in terms of the need to change was not part of a cognitive and deliberate decision-making process. This lack of deliberateness is in direct contrast to the business-oriented group who had mostly made very deliberate decisions to diversify within the fishery (especially in terms of craft).

The fishers in Vermaaklikheid were the least resilient group. Challenges brought about by the inability to access capital had resulted in the reacting group of fishers who would have liked to apply for rights, being unable to buy boats and equipment needed to comply with evaluation criteria used to allocate rights. ${ }^{29}$ This situation is in direct contrast to the two other groups whose access to capital had provided the opportunity to diversify within and outside the fishery to varying degrees. In the case of the reacting group, this lack of funds restricted access to the fishery overall. However, the reacting group would most likely benefit from the implementation of the new Small-scale Fisheries Policy. Whilst there are limitations and concerns with the implementation of the policy, ${ }^{45}$ successful implementation and management of the policy should benefit fishers in both Melkhoutfontein and Vermaaklikheid in terms of food security and social-ecological resilience.

\section{Conclusion}

We have highlighted change response strategies employed by participants in the commercial linefishery in the southern Cape to ensure and maintain sustainable livelihoods. These analyses provide insights into the varying levels of resilience displayed by the three broad groupings identified, as well as the costs and benefits of these different response types. The analyses offer a detailed description of strategies that are implemented, as well as some valuable insights into the decision-making processes. This discussion is by no means complete as a thorough evaluation with a focus on the reasoning in decision-making will provide much more insight into the rationale used by the fishers. An insight that emerges from these discussions with participants is that both cognitive and reflexive decision-making processes are shaped by individual and communities' experience of past and present environments. The practical implications of actions are not always the overriding concern in decision-making, which underscores the importance of culture and belief systems. There is also a recognition that the severity of the challenges experienced with policy and regulatory processes may be exacerbated by a strong resistance to change.

The insights gained from this research have rendered qualitative information that serves to provide insight into the daily lives of these groups of fishers - anchored in their own perspective. However, there is a lack of appropriately scaled quantitative data required to provide insight into, amongst others, household income, supply chains and networks, education levels, employmentstatus - all of which are crucial in developing an understanding of economic forces that give rise to environmental degradation whilst undermining sustainability. ${ }^{46}$ Whilst this research aimed to contribute towards understanding the current reacting, coping and adaptive strategies employed in fishing communities in the southern Cape, the interactions of these drivers and inter-relationships between the various strategies require better understanding. Understanding gained within this fishery system provides important insights into a system that has not been well described in the past, highlighting many knowledge gaps that need to be addressed by conducting further context-specific research at small scales. Following this study researchers will be in a better position to explore viable strategies for the future of these fishing communities through action research as a basis for regionally appropriate management recommendations.

\section{Acknowledgements}

The South African Research Chair Initiative, funded by the Department of Science and Technology and administered by the National Research Foundation (South Africa), provided bursary and research funding for L.C.G. through the Research Chair in Marine Ecology and Fisheries (A.J.). Our sincere thanks go to all research participants for offering up their time to participate in this project, to Lee-Anne Koller for transcribing the interviews and to the marine ecology and fisheries research group for editorial inputs.

\section{Authors' contributions}

The research was conducted as part of L.C.G.'s MSc, which was cosupervised by A.J. and C.M.

\section{References}

1. Jarre A, Ragaller SM, Hutchings L. Long-term, ecosystem-scale changes in the southern Benguela marine pelagic social-ecological system: Interaction of natural and human. Ecol Soc. 2013;18(4), Art. \#55, 15 pages. http://dx.doi. org/10.5751/ES-05917-180455

2. Ommer RE, Perry RI, Murray G, Neis B. Social-ecological dynamism, knowledge, and sustainable coastal marine fisheries. Curr Opin Environ Sustain. 2012;4(3):316-322. http://dx.doi.org/10.1016/j.cosust.2012.05.010

3. Isaacs $M$, Hara $M$, Raakjær J. Has reforming South African fisheries contributed to wealth redistribution and poverty alleviation? Ocean Coast Manag. 2007;50(5-6):301-313. http://dx.doi.org/10.1016/j. ocecoaman.2006.11.002

4. Van Sittert L. 'Those who cannot remember the past are condemned to repeat it': Comparing fisheries reforms in South Africa. Mar Policy. 2002;26(4):295305. https://doi.org/10.1016/S0308-597X(02)00012-X

5. Bennett NJ, Dearden P, Peredo AM. Vulnerability to multiple stressors in coastal communities: A study of the Andaman coast of Thailand. Clim Dev. 2015;7(2):37-41. http://dx.doi.org/10.1080/17565529.2014.886993

6. Bunce M, Brown K, Rosendo S. Policy misfits, climate change and crossscale vulnerability in coastal Africa: How development projects undermine resilience. Environ Sci Policy. 2010;13(6):485-497. http://dx.doi. org/10.1016/j.envsci.2010.06.003

7. Leichenko RM, O'Brien K. Environmental change and globalisation: Double exposures. New York: Oxford University Press; 2008.

8. O'Brien KL, Leichenko RM. Double exposure: Assessing the impacts of climate change within the context of economic globalization. Glob Environ Chang. 2000;10:221-232. http://dx.doi.org/10.1016/S0959-3780(00)00021-2

9. Ommer RE, and the Coasts under stress team. Coasts under stress: Restructuring and social-ecological health. Montreal and Kingston: McGillQueen's University Press; 2007.

10. Adger WN, Hughes TP, Folke C, Carpenter SR, Rockström J. Social-ecological resilience to coastal disasters. Science. 2005;309(5737):1036-1039. http:// dx.doi.org/10.1126/science.1112122

11. Cinner J, Fuentes MMPB, Randriamahazo H. Exploring social resilience in Madagascar's marine protected areas. Ecol Soc. 2009;14(1), Art. \#41, 20 pages. Available from: http://www.ecologyandsociety.org/vol14/iss1/art41/

12. Bennett NJ, Dearden P, Murray G, Kadfak A. The capacity to adapt?: Communities in a changing climate, environment, and economy on the northern Andaman coast of Thailand. Ecol Soc. 2014;9(2), Art. \#5, 20 pages. http://dx.doi.org/10.5751/ES-06315-190205

13. Marschke MJ, Berkes F. Exploring strategies that build livelihood resilience: A case from Cambodia. Ecol Soc. 2006;11(1), Art. \#42, 16 pages. Available from: http://www.ecologyandsociety.org/vol11/iss1/art42/

14. De Haan L, Zoomers A. Development geography at the crossroads of livelihood and globalisation. Tijdschr voor Econ en Soc Geogr. 2003;94(3):350-362. https://doi.org/10.1111/1467-9663.00262

15. Taylor PJ. A materialist framework for political geography. Trans Inst Br Geogr. 1982;7(1):15-34. http://dx.doi.org/10.2307/621909 
16. De Haan L, Zoomers A. Exploring the frontier of livelihoods research. Dev Change. 2005;36(1):27-47. http://dx.doi.org/10.1111/j.0012155X.2005.00401.X

17. Kirkby J, O'Keefe P, Howorth C. Introduction: Rethinking environment and development in Africa and Asia. Land Degrad Dev. 2001;12(3):195-203. http://dx.doi.org/10.1002//dr.431

18. Berkes F, Colding J, Folke C, editors. Navigating social-ecological systems: Building resilience for complexity and change. New York: Cambridge University Press; 2003.

19. Folke C. Resilience: The emergence of a perspective for social-ecological systems analyses. Glob Environ Chang. 2006;16(3):253-267. http://dx.doi. org/10.1016/j.gloenvcha.2006.04.002

20. Folke C, Carpenter S, Elmqvist T, Gunderson L, Holling CS, Walker B. Resilience and sustainable development: Building adaptive capacity in a world of transformations. Ambio. 2002;31(5):437-440. http://dx.doi. org/10.1579/0044-7447-31.5.437

21. Cinner JE, Folke C, Daw T, Hicks CC. Responding to change: Using scenarios to understand how socioeconomic factors may influence amplifying or dampening exploitation feedbacks among Tanzanian fishers. Glob Environ Chang. 2011;21(1):7-12. http://dx.doi.org/ 10.1016/j. gloenvcha.2010.09.001

22. Cinner JE, McClanahan TR, Graham NAJ, Daw TM, Maina J, Stead SM, et al. Vulnerability of coastal communities to key impacts of climate change on coral reef fisheries. Glob Environ Chang. 2012;22(1):12-20. http://dx.doi. org/10.1016/.j.gloenvcha.2011.09.018

23. Benguela Current Commission. Benguela Current Commission [homepage on the Internet]. c2013 [cited 2016 Jul 15]. Available from: http://www. benguelacc.org/index.php/en/about/the-bclme

24. Hutchings L, Van der Lingen CD, Shannon LJ, Crawford RJM, Verheye HMS, Bartholomae $\mathrm{CH}$, et al. The Benguela Current: An ecosystem of four components. Prog Oceanogr. 2009;83(1-4):15-32. http://dx.doi. org/10.1016/j.pocean.2009.07.046

25. Jarre A, Hutchings L, Kirkman S, Kreiner A, Tchipalanga P, Kainge $P$, et al. Synthesis: Climate effects on biodiversity, abundance and distribution of marine organisms in the Benguela. Fish Oceanogr. 2015;24(Suppl 1):122149. http://dx.doi.org/10.1111/fog.12086

26. Griffiths MH. Long-term trends in catch and effort of commercial linefish off South Africa's Cape Province: Snapshots of the 20th century. S Afr J Mar Sci. 2000;22(1):81-110. http://dx.doi.org/10.2989/025776100784125663

27. Blamey LK, Shannon LJ, Bolton JJ, Crawford RM, Dufois F, Evers-King H, et al. Ecosystem change in the southern Benguela and the underlying processes. J Mar Syst. 2015;144:9-29. http://dx.doi.org/10.1016/j.jmarsys.2014.11.006

28. Adger WN. Vulnerability. Glob Environ Chang. 2006;16(3):268-281. http:// dx.doi.org/10.1016/j.gloenvcha.2006.02.006

29. Gammage LC, Jarre A, Mather C. A case study from the southern Cape linefishery 1: The difficulty of fishing in a changing world. S Afr J Sci. 2017;113(5/6), Art. \#2016-0252, 8 pages. http://dx.doi.org/10.17159/ sajs.2017/20160252

30. Gammage LC. Considering one's option when the fish leave: a case study of the traditional commercial linefishery of the Southern Cape [master's dissertation]. Cape Town: University of Cape Town; 2015. Available from: https://open.uct.ac.za/handle/11427/15479
31. Perry RI, Ommer RE, Barange M, Jentoft $\mathrm{S}$, Neis B, Sumaila UR. Marine social-ecological responses to environmental change and the impacts of globalization. Fish Fisheries. 2011;12(4):427-450. http://dx.doi.org/10.1111/ j.1467-2979.2010.00402.x

32. Winker H, Kerwath SE, Attwood CG. Report on age-structured stock assessments and the simulation of the impacts of various fisheries management options for the South African linefishery. Report no. LSWG II. Pretoria: Department of Agriculture, Forestry and Fisheries; 2014.

33. Visser $\mathrm{N}$. The origins of the present: Economic conflicts in the fisheries of the South African south east coast, circa 1910 - 1950. Marit Stud. 2015;14(1):9. http://dx.doi.org/10.1186/s40152-015-0029-6

34. Duggan GL, Green LJF, Jarre A. "Thinking like a fish": Adaptive strategies for coping with vulnerability and variability emerging from a relational engagement with kob. Marit Stud. 2014;4(13):1-21. http://dx.doi.org/10.1186/22129790-13-4

35. Coulthard S. Adapting to environmental change in artisanal fisheries Insights from a south Indian lagoon. Glob Environ Chang. 2008;18(3):479489. http://dx.doi.org/10.1016/j.gloenvcha.2011.01.003

36. Smit B, Wandel J. Adaptation, adaptive capacity and vulnerability. Glob Environ Chang. 2006;16(3):282-292. http://dx.doi.org/10.1016/j. gloenvcha.2006.03.008

37. South African Department of Environmental Affairs. Working for Water (WfW) programme [homepage on the Internet]. No date [cited 2016 Aug 01]. Available from: https://www.environment.gov.za/projectsprogrammes/wfw

38. Isaacs M. Small-scale fisheries reform: Expectations, hopes and dreams of 'a better life for all'. Mar Policy. 2006;30(1):51-59. http://dx.doi.org/10.1016/j. marpol.2005.06.010

39. Sowman M. Subsistence and small-scale fisheries in South Africa: A tenyear review. Mar Policy. 2006;30(1):60-73. https://dx.doi.org/10.1016/j. marpol.2005.06.014

40. Ellis $F$, Allison E. Livelihood diversification and natural resource access. Norwich: Overseas Development Group, University of East Anglia; 2004.

41. Welcome to the Overberg.co.za [homepage on the Internet]. No date [cited 2016 Aug 01]. Available from: http://www.overberg.co.za/content/ view/142/27/

42. Walker B, Meyers JA. Thresholds in ecological and social-ecological systems: A developing database. Ecol Soc. 2004;9(2), Art. \#3, 16 pages. http://www.ecologyandsociety.org/vol9/iss2/art3/

43. Gunderson L, Holling C, editors. Panarchy: Understanding transformations in human and natural systems. Washington: Island Press; 2002.

44. Scheffer M, Carpenter S, Foley JA, Folke C, Walker B. Catastrophic shifts in ecosystems. Nature. 2001;413(10):591-596. https://dx.doi. org/10.1038/35098000

45. Sowman M, Sunde J, Raemaekers S, Schultz 0 . Fishing for equality: Policy for poverty alleviation for South Africa's small-scale fisheries. Mar Policy. 2014;46:31-42. http://dx.doi.org/10.1016/j.marpol.2013.12.005

46. Sowman M, Scott D, Green LJF, Hara MM, Hauck M, Kirsten K, et al. Shallow waters: Social science research in South Africa's marine environment. Afr J Mar Sci. 2013;35(3):385-402. http://dx.doi.org/10.2989/181423 2X.2013.836134 